\title{
Stratigraphy, tectonics and detrital zircon U-Pb (LA-ICP-MS) geochronology of the Rio Preto Belt and northern Paramirim corridor, NE, Brazil
}

\author{
Estratigrafia, tectônica e geocronologia U-Pb (LA-ICP-MS) \\ em zircão detrítico da faixa Rio Preto e porção norte \\ do corredor do Paramirim, NE, Brasil
}

\author{
Davi da Costa Bezerra Gobira de Alcântara ${ }^{1 *}$, Alexandre Uhlein ${ }^{1}$, \\ Fabrício de Andrade Caxito ${ }^{1}$, Ivo Dussin ${ }^{2}$, Antônio Carlos Pedrosa-Soares ${ }^{1}$
}

\begin{abstract}
Two important Proterozoic metasedimentary sequences, the Rio Preto and Santo Onofre Groups, crop out along the northwestern margin of the Sáo Francisco craton and in northern Paramirim corridor, respectively. The Rio Preto Group, involved in the eponymous fold-thrust belt along the northwestern cratonic boundary, comprises the Formosa (garnet schist, quartz-mica schist, quartzite, chlorite-sericite schist and ferriferous quartz schist) and Canabravinha (quartzite, micaceous quartzite, metarhytmite, phylite, schist and metaturbidite) formations. The Santo Onofre Group occurs exclusively in the Paramirim corridor, and is composed of quartzite and minor carbonaceous or $\mathrm{Mn}$-rich phylite. These units record sedimentation in shallow to deep-water marine settings related to rift basins, and were deformed and metamorphosed under greenschist facies conditions during the Brasiliano orogeny. Here we present 427 new detrital zircon U-Pb ages, which constrain the maximum depositional ages of ca. $971 \mathrm{Ma}$ for the Santo Onofre Group, ca. 912 Ma for the Canabravinha Formation, and ca. $965 \mathrm{Ma}$ for the Formosa Formation of the Rio Preto Group. Our data suggests that the Santo Onofre and the Rio Preto Groups accumulated in two distinct basin settings. The latter, composed mostly of sandy rocks, would represent a relatively stable, shallow-marine shelf environment. The Rio Preto Group, with metadiamictite, quartzite, pelitic and rhythmitic rocks, represents a shallow to deep marine environment influenced by gravity flows. Both groups were probably deposited in the Late Tonian, and are potential correlatives of the lower (pre-glacial) units of the Macaúbas Group of the Araçuaí belt.
\end{abstract}

KEYWORDS: Detrital zircon U-Pb geochronology, Brasiliano orogeny, sedimentary provenance, Rio Preto Belt, Paramirim corridor.

\begin{abstract}
RESUMO: Duas importantes sequências metassedimentares proterozoicas ocorrem ao longo da margem noroeste do Cráton do São Francisco e a porçấo setentrional do Corredor do Paramirim, os grupos Rio Preto e Santo Onofre, respectivamente. O Grupo Rio Preto, que constitui a faixa homônima situada no limite noroeste cratônico, é composto pelas formaçôes Formosa (xisto granatifero, quartzo-mica xisto, quartzito, clorita-sericita xisto e quartzo xisto ferrifero) e Canabravinha (quartzito, quartzito micáceo, metaritmito, filito, xisto e metaturbidito). O Grupo Santo Onofre ocorre exclusivamente na regiāo do Corredor do Paramirim, e é composto por quartzitos e subordinadamente filitos sericíticos, carbonosos ou manganesiferos. As duas unidades estratigráficas registram a sedimentação associada a um ambiente marinho raso a profundo, $e$ são interpretadas como bacias rift invertidas e metamorfisadas na fácies xisto verde durante a orogênese brasiliana. Neste artigo apresentamos 427 idades U-Pb em zircōes detriticos para essas unidades. Os novos dados apresentaram idades máximas de deposição de 912 Ma para Formação Canabravinha, 965 Ma para a Formação Formosa e 971 Ma para o Grupo Santo Onofre. Portanto, é sugerida a existência de duas bacias rift neoproterozoicas formadas pelos Grupos Rio Preto e Santo Onofre. O Grupo Santo Onofre, predominantemente psamitico, representaria um ambiente marinho raso plataformal relativamente estável. O Grupo Rio Preto, com diamictito, quartzito, pelito e ritmito, representaria um ambiente marinho raso a profundo associado a fluxos gravitacionais. Ambos os grupos teriam sido depositados no Toniano tardio, e são possivelmente correlacionados com as unidades inferiores (pré-glaciais) do Grupo Macaúbas, localizado na Faixa Araçuaí.
\end{abstract}

PALAVRAS-CHAVE: Geocronologia U-Pb em zircão detrítico, orogênese brasiliana, proveniência sedimentar, Faixa Rio Preto, Corredor do Paramirim.

\footnotetext{
${ }^{1}$ Programa de Pós-Graduação em Geologia, Centro de Pesquisa Professor Manoel Teixeira da Costa - CPMTC, Instituto de Geociências, Universidade Federal de Minas Gerais - UFMG, Belo Horizonte (MG),Brazil.E-mails: davibgobira@hotmail.com; auhlein@gmail.com; facaxito@yahoo.com.br; pedrosasoares@gmail.com ${ }^{2}$ Multilab, Faculdade de Geologia, Universidade Estadual do Rio de Janeiro - UERJ, Rio de Janeiro (RJ), Brazil. E-mail: ivodusin@yahoo.com.br *Corresponding author.

Manuscript ID: 20160102. Received in: 08/17/2016. Approved in: 05/17/2017
} 


\section{INTRODUCTION}

The late Precambrian geotectonic panorama of the South American platform was established during the diachronic Brasiliano orogenies, when cratonic blocks were amalgamated along Neoproterozoic orogenic belts. In this scenario, we focus on São Francisco Craton and its northwestern margin, occupied by the marginal Rio Preto Belt (Almeida et al. 2000).

From the Statherian to the Cryogenian, the São Francisco-Congo paleocontinent experienced several rifting events, recorded by anorogenic magmatic rocks and sedimentary sequences in the regions of the Espinhaço-Chapada Diamantina basin system (ca. $1.75 \mathrm{Ga}$, ca. 1.5 Ga, and ca. 1.2 Ga; Danderfer et al. 2009; Chemale et al. 2012), and the Macaúbas-Santo Onofre-West Congo basin system (ca. $1 \mathrm{Ga}$, ca. 930-870 Ma, and ca. 720-670 Ga; Schobbenhaus 1996, Pedrosa-Soares et al. 2008, Silva et al. 2008; Thiéblemont et al. 2009, Pedrosa-Soares \& Alkmim 2011, Straathof 2011, Caxito et al. 2014a, Kuchenbecker et al. 2015, Affatton et al. 2016). During the Tonian, the main rifting event lasted from ca. 930 to ca. $870 \mathrm{Ma}$, as indicated by $\mathrm{U}-\mathrm{Pb}$ zircon ages of anorogenic igneous rocks (Pedrosa Soares \& Alkmim 2011). This event led to the development of an extensive rift system exposed in Rio Preto Belt (Caxito et al. 2014a), Paramirim corridor of São Francisco Craton (Schobbenhaus 1996, Danderfer \& Dardenne 2002), Araçuaí Belt (Pedrosa-Soares et al. 2008, Kuchenbecker et al. 2015), and Riacho do Pontal Belt (Caxito et al. 2016, 2017). Schobbenhaus (1996) suggests the name Araçuaí-Paramirim-Rio Preto System to correlate all these basins, which characterize a triple junction of rift arms formed during the early Neoproterozoic.

Santo Onofre Group corresponds to the unit redefined by Schobbenhaus (1996) after Sítio Novo and Santo Onofre formations (Inda \& Barbosa 1978). In the studied region, Santo Onofre Group occurs along Boqueirão and Estreito ridges (Fig. 1). Rio Preto Group includes Canabravinha and Formosa Formations. Caxito (2010) interpreted these units as representative of a single basin, whereas Egydio-Silva et al. (1989) and Caxito et al. (2014a) potrayed them as two distinct basins, deformed and metamorphosed during the Brasiliano Orogeny.

This paper presents new geologic, statigraphic and structural data, as well as U-Pb ages obtained on detrital zircon grains from Santo Onofre and Rio Preto Groups. Our data support new interpretations on the chronostatigraphy of these sequences and clarify the relation between Rio Preto Belt and the northern Paramirim corridor. The focused region is a key zone to understand sedimentation and orogenic processes that can connect Rio Preto and Riacho do Pontal belts along the boundary between Borborema and Sáo Francisco provinces.

\section{GEOLOGICAL CONTEXT}

The target of this research is a $33,508 \mathrm{~km}^{2}$ area located on the NW boundary of São Francisco Craton, involving Rio Preto Belt and the northern Paramirim corridor, in northwestern Bahia and south of Piauí states (Figs. 1 and 2). Cross-sections were made in nearly six weeks of fieldwork. A new geological map was prepared from field data, remote-sensing imagery interpretation and compilation of previous geological surveys (Fig. 1).

The most important basic geological mapping performed in the study area are those of Inda and Barbosa (1978), Andrade Filho et al. (1994) and Arcanjo and Braz Filho (2001), corresponding to a government initiative from Companhia de Pesquisa de Recursos Minerais (CPRM) and Companhia Baiana de Pesquisa Mineral (CBPM). Barbosa (1982) studied the manganese occurences of the focused region and Egydio-Silva (1987) conducted a lithostratigraphic, structural and geochronological (Rb-Sr and $\mathrm{K}-\mathrm{Ar}$ ) investigation on the units involved in Rio Preto Belt and adjacent cratonic area. Caxito (2010) carried out a stratigraphic, structural, geochemical and geochronological investigation on Canabravinha and Formosa Formations in the area located between the towns of Cristalândia do Piauí and Monte Alegre dos Cardosos. Caxito et al. (2014a) used U-Pb and Sm-Nd isotopic analyses to propose a new chronostatigraphic subdivision of Canabravinha and Formosa Formations.

\section{Stratigraphy}

The main outcropping units of the study area are the Archean/Rhyacian high-grade metamorphic basement (composed of Cristalândia do Piauí Complex and Mansidão Granite), the Neoproterozoic granitic intrusions of Serra da Pintada Suite, and the metasedimentary rocks of Rio Preto, Santo Onofre and Bambuí groups (Fig. 1).

Rio Preto Belt and the northern Paramirim corridor share the same regional basement composed of the Cristalândia do Piauí Complex and the intrusive Mansidão Granitic Body. Cristalândia do Piauí Complex consists of biotite and hornblende gneisses, locally migmatized or with augen texture, interleaved with metaultrabasic and metabasic rocks. The available geochrological data correspond to a ca. 2.1 Ga $\mathrm{Rb}-\mathrm{Sr}$ whole rock isocron age, ca. $540 \mathrm{Ma} \mathrm{K}$-Ar biotite ages (Egydio-Silva et al. 1989), as well as ca. 2.7 Ga Sm-Nd (TDM) model ages (Caxito 2010; Caxito et al. 2014a). These data suggest the presence of a Neoarchean crust reworked during Paleoproterozoic and Neoproterozoic orogenic events.

Mansidão Granite shows a tonalitic composition and amphibolite facies metamorphism. Mascarenhas and Garcia (1989) obtained a 2.046 Ma Rb-Sr isochron age (with initial ratio of 0.7016 ), as well as a $600 \mathrm{Ma} \mathrm{K}$-Ar age for this 


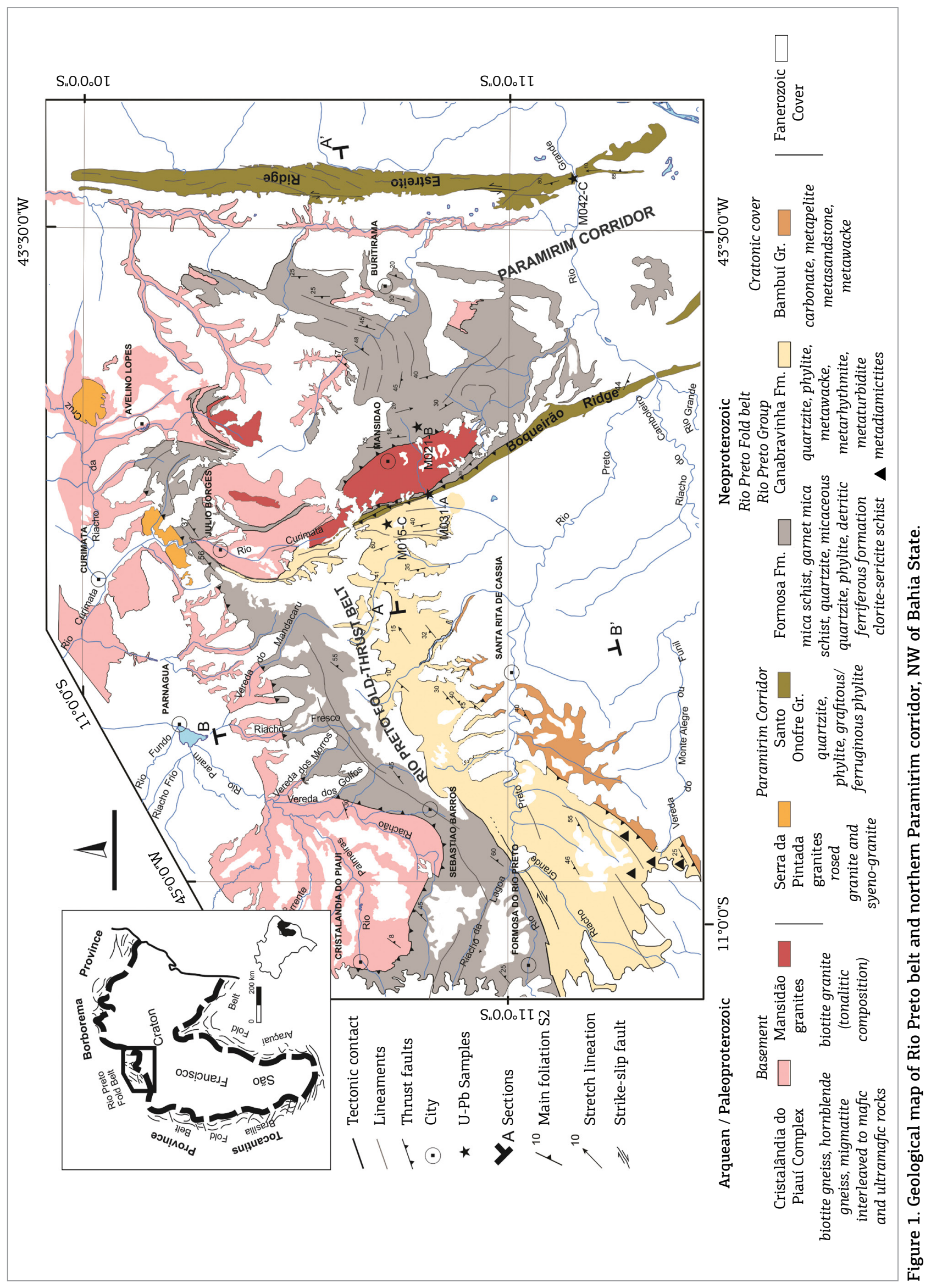


unit, suggesting a Rhyacian emplacement age and reworking in the Late Neoproterozoic.

Rosed, porphyritic, coarse-grained, highly deformed granite and syeno-granite composes Serra da Pintada Suite. Geochemical studies indicate peraluminous to peralkaline composition and an A-Type signature (Aquino \& Batista 2011). These authors also present a zircon U-Pb Concordia age of $969 \pm 11 \mathrm{Ma}(\mathrm{MSDW}=0.72$ ), interpreting these intrusions as a manifestation of a Tonian rift-related plutonism.

Santo Onofre Group occurs exclusively along Boqueirão and Estreito ridges, two outstanding geomorphological features oriented in NNW and NS directions. The group is composed of pure quartzites, micaceous quartzites and minor sericitic, hematitic, Mn-rich or carbonous phyllites. The lithologies above are milimetric to decametric interleaved. This metasedimentary sequence is interpreted as a restricted, marine package, accummulated in a reducing environment (Schobbenhaus 1996). Sand plains and offshore bars deposits related to a shelf environment have also been described in the group by Uhlein and Pedreira (1989).

Rio Preto Group is subdivided into Canabravinha and Formosa Formations. Formosa Formation is an heterogeneous unit that crops out from the town of Formosa do Rio Preto (type area defined by Caxito 2010 and Caxito et al. 2012) to the interior of the Paramirim corridor, between Boqueirão and Estreito ridges (previously mapped as Rio Preto Group by Inda \& Barbosa 1978; Barbosa \& Domingues 1996; Vasconcelos et al. 2004). Mica schist and quartz-mica schist, locally graphite- or garnet/magnetite-rich, chlorite-sericite schist, quartzite, and ferriferous quartz schist compose Formosa Formation (Fig. 3). These lithotypes show sharp or gradational contacts with each other. The contact of Formosa Formation with the basement and Santo Onofre Group is tectonic. The tectonic contact with Canabravinha Formation is well exposed in the type area, being however covered by recent sediments in its eastern portion (Fig. 2). Detrital zircon $\mathrm{U}-\mathrm{Pb}$ and $\mathrm{Sm}-\mathrm{Nd}$ isotopic data available for Formosa Formation in the type area reveal a bimodal age pattern of 1.9-2.2 Ga and 2.5-2.6 Ga, and TDM model ages of 1.9 to $2.6 \mathrm{Ga}$ (Caxito 2010; Caxito et al. 2014a). Highly negative $\varepsilon N d$ values (-13.0 and -26.5$)$ suggest an intensively reworked crust as the main sediment source. An amphibolite body interleaved with the metasedimentary rocks was dated at $1,958.3 \pm 16 \mathrm{Ma}$ (zircon U-Pb Concordia age) by Caxito et al. (2015).

Quartzite, micaceous quartzite, quartz schist, metarhytmite, metadiamictite and sericitic phylite (locally carbonous, pyrite or Mn-rich) compose Canabravinha Formation (Fig. 3). Locally, micaceous quartzites were recognized as sand metaturbidites. This association is interpreted as deposited in a deep marine slope-apron environment (Uhlein et al. 2011; Caxito 2010; Caxito et al. 2012, 2014a). This formation has tectonic contact with the Bambuí Group through a south vergent thrust fault, while the contact with Santo Onofre Group, on Boqueirão Ridge, is an east vergent thrust fault (Fig. 2). The detrital zircon U-Pb age spectra indicate 850 to 3,000 Ma sources, and model ages varying from 1.5 to $2.7 \mathrm{Ga}(\varepsilon \mathrm{Nd}$ values ranging from -8.7 to -19.5$)$ (Caxito et al. 2014a).

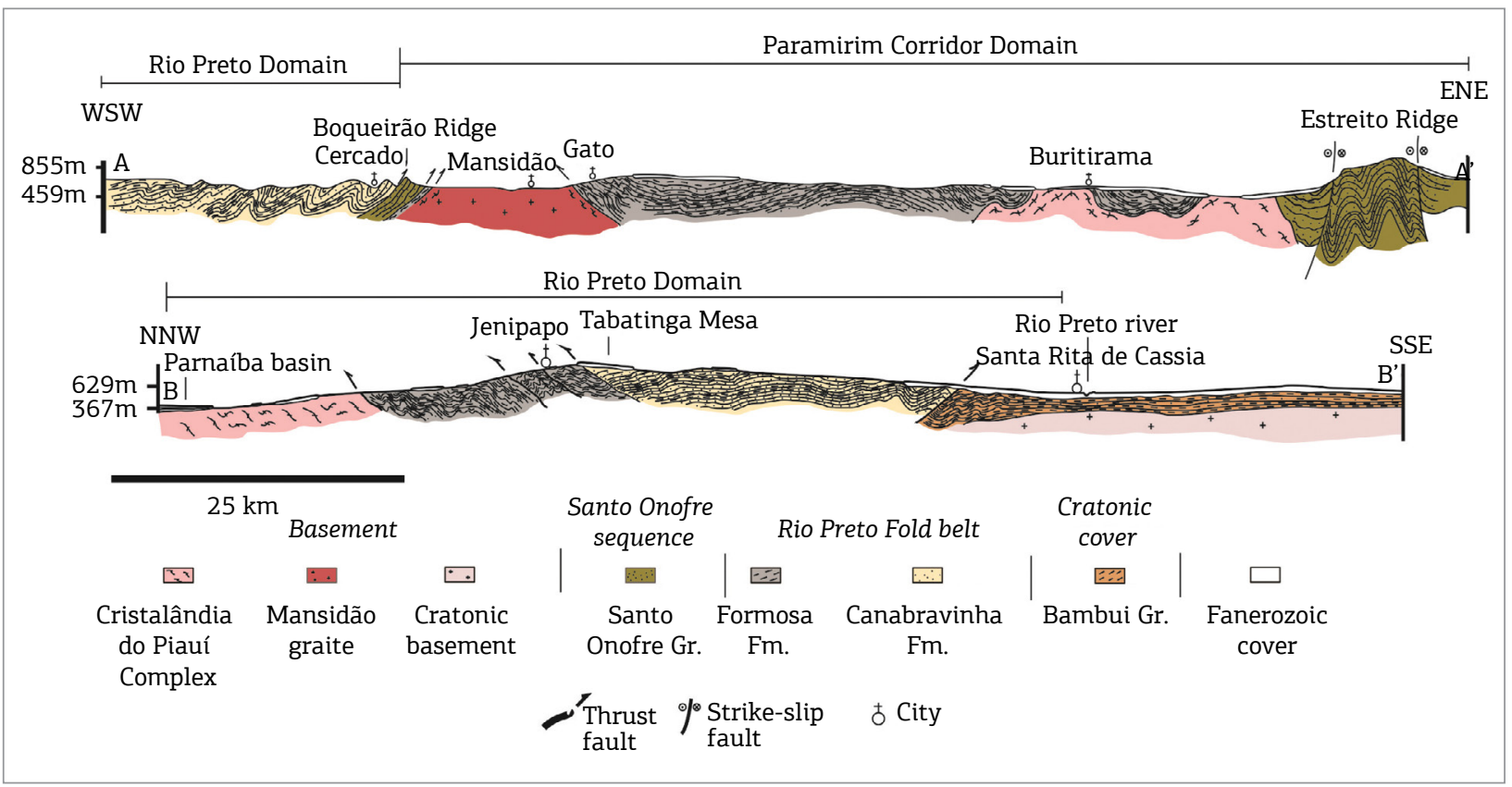

Figure 2. Geological sections A-A' and B-B' of the study area. Location of the sections are indicated on Figure1. 
Bambuí Group crops out in the southern part of the focused region (Fig. 1) and represents the extension of Serra da Mamona and Riachão das Neves formations, characterized by Egydio-Silva (1987). Serra da Mamona Formation consists of interleaved layers of metapelites and metacarbonates, while metawackes, metarkoses and metasiltstones characterize Riachão das Neves Formation.

\section{Structure}

The study area shows interference of two distinct generations of tectonic structures associated with the West Gondwana amalgamation (Alkmim et al. 2001). The NS-striking structures of the Paramirim corridor probably represent the propagation of the Araçuaí orogenic front toward the interior of São Francisco Craton, and the WSW-ESE-trending of Rio Preto Belt, the inversion of a preexistent rift structure along the NW craton margin.
As previously described by Egydio-Silva (1987), Caxito (2010) and Caxito et al. (2014c), three deformation phases are recorded in the study area. An S1 foliation, which occurs in microlithons within S2 planes (main foliation) in schists, and phyllites represent the first phase (Fig. 4). The second phase is responsible for the generation of the regionally dominant structures and the S2 foliation, which is observed in field as a crenulation cleavage. Kinematic indicators associated to S2 indicate SSE sense of shear, i.e., towards the craton on the southern section of Rio Preto Belt, and NW-direct tectonic motion in its northern portion. This foliation is related to a down-dip mineral lineation, assimetric and isoclinal folds and thrust faults (Figs. 1 and 2). The third phase is represented by a spaced crenulation cleavage, better developed in metapelitic layers.

The tectonic panorama of Rio Preto Belt and the Paramirim corridor are illustrated by two regional cross-sections shown on Figure 2. The B-B' section has an approximately N-S
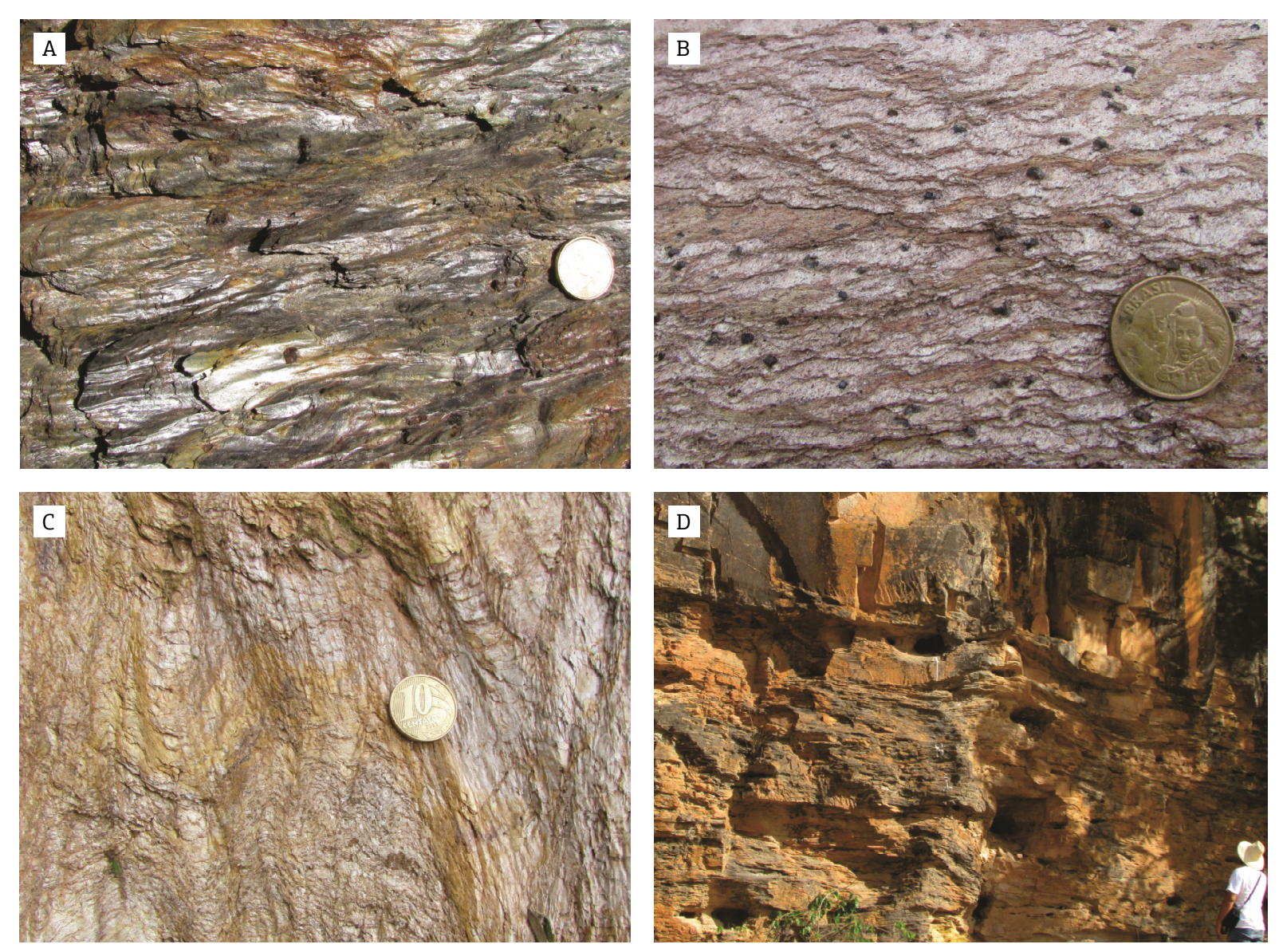

Figure 3. Outcrops of studied units. (A) Outcrop M018 (610 734 E, 8809257 N, Datum WGS84), in Gato district. Typical crenulated garnet-mica schist of the Formosa Formation; (B) Outcrop M174 (556259 E, 8834666 N). Crenulated mica schist with magnetite of Formosa Formation; (C) Outcrop M067 (533514 E, 8803901 N). Phylite of Canabravinha Formation; (D) Outcrop M183 (557455 E, 8814111 N). Lower quartz schist layer (better developed foliation) and an upper layer of quartzite of the Canabravinha Formation. 
orientation and shows Rio Preto Belt framework, in which we highlight the divergent fan structure related to the second deformation phase. The S2 foliation dips NW on the south, and $S$ in the northern segment of the belt. The A-A' section shows the influence of Rio Preto Belt deformation on the Paramirim corridor, especially on Boqueirão Ridge. In this region, the NE-SW trending Rio Preto Belt bends toward $\mathrm{N}$, surrounding the Paramirim corridor. To the north of Mansidão and Buritirama, schists of Formosa Formation are highly deformed along the contact with milonitized gneiss. Along the NS-oriented Estreito Ridge, bedding affected by tight and isoclinal folds is nearly vertical and the penetrative foliation is associated with a sub-horizontal NS-trending lineation. These structures probably relate to NS-oriented strike-slip faults propagated from the southern Paramirim corridor.

\section{DETRITAL ZIRCON U-PB GEOCHRONOLOGY OF SANTO ONOFRE AND RIO PRETO GROUPS}

\section{Materials and methods}

For zircon analyses, four samples were collected: one from Canabravinha Formation (sample M015-C), one from Formosa Formation (sample M021-B), and two samples from Santo Onofre Group (samples M031-A and M042-C) (Fig. 1). From about $16 \mathrm{~kg}$ of the four samples, 608 zircons grains were separated by standard milling, handpicking, and magnetic techniques at the sample preparation laboratory (LGPA) and geochronology laboratory (Multilab) of the Universidade Estadual do Rio de Janeiro (UERJ), Brazil. The grains from each sample were mounted in a circular
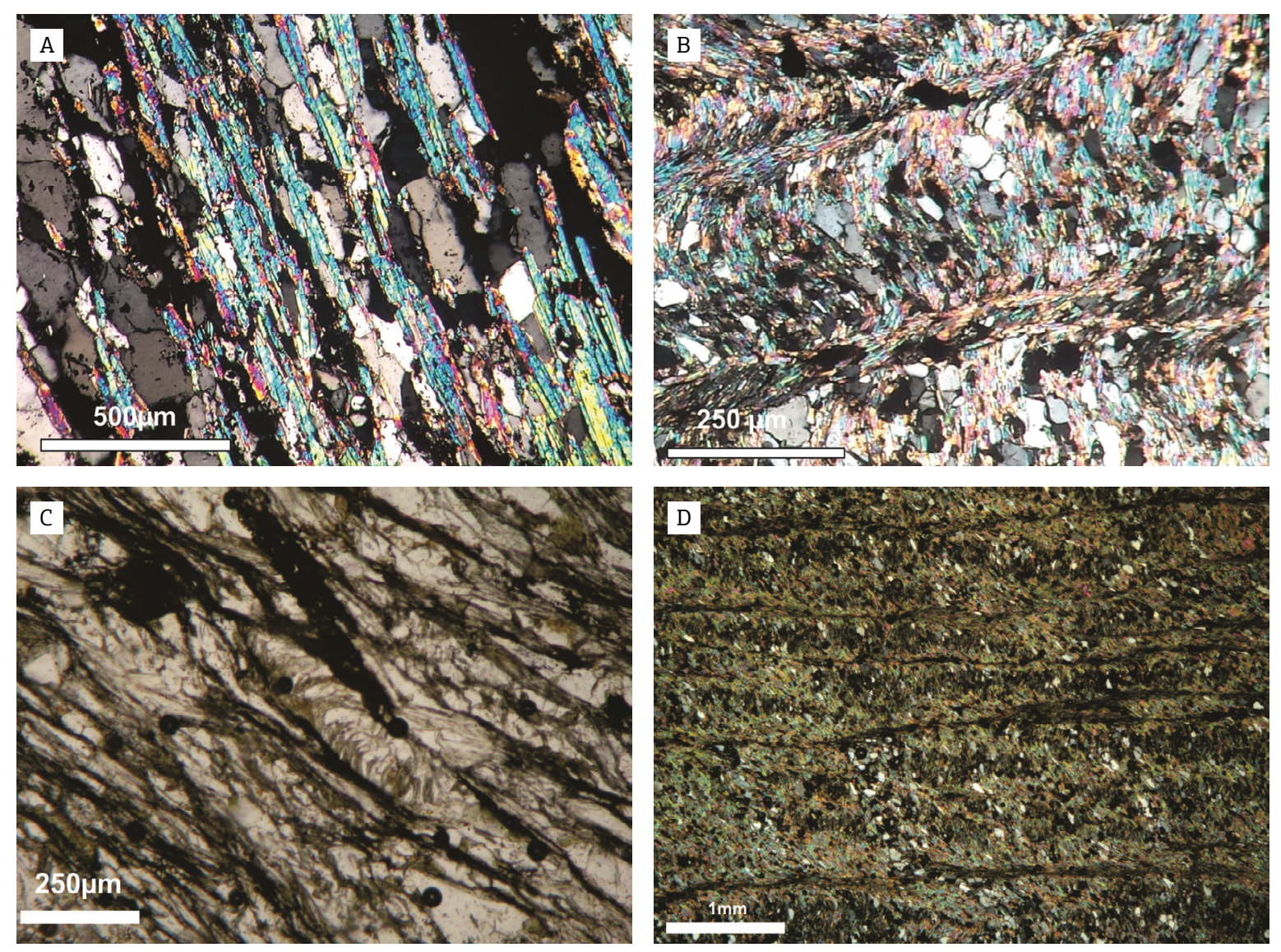

Figure 4. Photomicrography of tectonic structures. (A) Thin section M025A (646756 E, 8813164 N), showing the ferriferous quartz schist of Formosa Fm., located near the Buritirama City. In this figure and Figure 4B (Canabravinha Fm.), we can compare the average size of muscovites and quartz grains of both formations. This shows a higher metamorphic facies for the Formosa Fm. Crossed polarizers, 10x; (B) Thin section M127A. Phylite of the Canabravinha Formation with crossed polarizers, 10x; (C) Thin section M033A. Chlorite-sericite schist of the Formosa Formation. In this picture, we observe the foliation S1, almost totally obstructed, preserved in a small microlithon, surrounded and transposed by the main foliation S2. Parallel polarizers, 10x; (D) Thin section M127A. Phyllite of the Canabravinha Formation. Foliation S1 within microlithons cut by Foliation S2. Crossed polarizers, $2.5 \mathrm{x}$. 
epoxy and polished to expose their interiors. The morphology and internal structure of zircons were characterized by optical microscopy and cathodoluminescence (CL) imaging.

The isotopic analyses were carried out in two sessions. The first was conducted at the Geology Department (Departamento de Geologia), Universidade Federal de Ouro Preto, Brazil, and samples M015-C, M021-B and M042-C were analysed. This analytical session was conducted in a Thermo Scientific Element 2 Sector Field (SF) ICP-MS coupled to a CETAC LSX-213 G2+ laser. The reference zircon M127 (Klotzli et al. 2009) was used as primary standard. For complementary quality control, a secondary standard was adopted using the Plešovice reference zircon (Slama et al. 2008). Additional detailed methodology can be found in Chemale et al. (2012). The LA-ICPMS data were reduced using the Glitter Software (Van Achterbergh et al. 2001).

The latter sample, M031-A, was examined in a second analytical session at Multilab, in UERJ, Brazil. The session was conducted in a Neptune Thermo Scientific LA-MC-ICP-MS (25 $\mu \mathrm{m}$ spot size). The zircon GJ-1 (Jackson et al. 2004) was used as standard, analysed twice every 6 sample grain analyses. Analytical spots were conducted avoiding grain areas with inclusions, fractures and metamictic structures. An Excel sheet developed by Chemale et al. (2012) was used to data reduction. Further methodology can be found in Gonçalves et al. (2016).

For all samples, the data of each spot were evaluated taking into account common $\mathrm{Pb}$ contents, errors of isotopic ratios, percentages of discordance and $\mathrm{Th} / \mathrm{U}$ ratios. Selected spots used for age calculations were those with discordance lower than $10 \%$. The isotopic ages were calculated and plotted using Isoplot 4.15 (Ludwig 2008). Uncertainties given for analyses (ratios and ages) are at the 1 sigma level, in percentage. U-Pb analytical data are shown as Supplementary data.

\section{Results}

From 608 zircons obtained during the preparation, 427 showed less than $10 \%$ discordance and $\mathrm{Th} / \mathrm{U}$ ratio above 0.07 . Figure 5 shows CL images with spot location of representative zircons of each analysed sample. The results are shown in ${ }^{207} \mathrm{~Pb} /{ }^{206} \mathrm{~Pb}$ age histograms (bin size: $50 \mathrm{Ma}$ ) (Figs. 6A to D) and probability density plots created in Isoplot 4.15 software (Ludwig 2008).

\section{Canabravinha Formation - Sample M015-C}

Sample M015-C is a quartzite collected in the Cercado region, $30 \mathrm{~km}$ from the town of Santa Rita de Cassia (590977 E, 8815710 N, Datum WGS89). From 128 zircon grains separated in this sample, 93 are concordant within $10 \%$. The zircon crystals and fragments show sizes between 290 and $90 \mu \mathrm{m}$. They are mostly rounded to subrounded, spherical to prismatic, predominantly zoned and with few fractures. The major age concentration shows up at 2,100 Ma. Other importants peaks occur at 920, 1,220, 1,330, 1,460, 1,570, 1,770, 2,360, 2,480, 2,730 and 2,900 Ma (Fig. 6A). The two youngest concordant zircons show ages of $912 \pm 8$ and $921 \pm 9 \mathrm{Ma}$. The oldest concordant zircon shows an age of $2,902 \pm 18 \mathrm{Ma}$.

\section{Formosa Formation - Sample M021-B}

The M021-B sample is from a micaceous quartzite that outcrops near Gato district, $10 \mathrm{~km}$ from Mansidão City (614225 E, 8808179 N, Datum WGS89). One hundred and fifty (150) zircons were separated from this sample, and 91 grains show less than $10 \%$ discordance. The grains and fragments exhibit sizes between 300 and $70 \mu \mathrm{m}$. They are rounded to subangular, with high sphericity to prismatic, zoned or untextured. The sample showed a main peak at 2,170 Ma. Other peaks are at $970,1,200,1,350,1,540,1,750,1,860,2,080,2,360$,

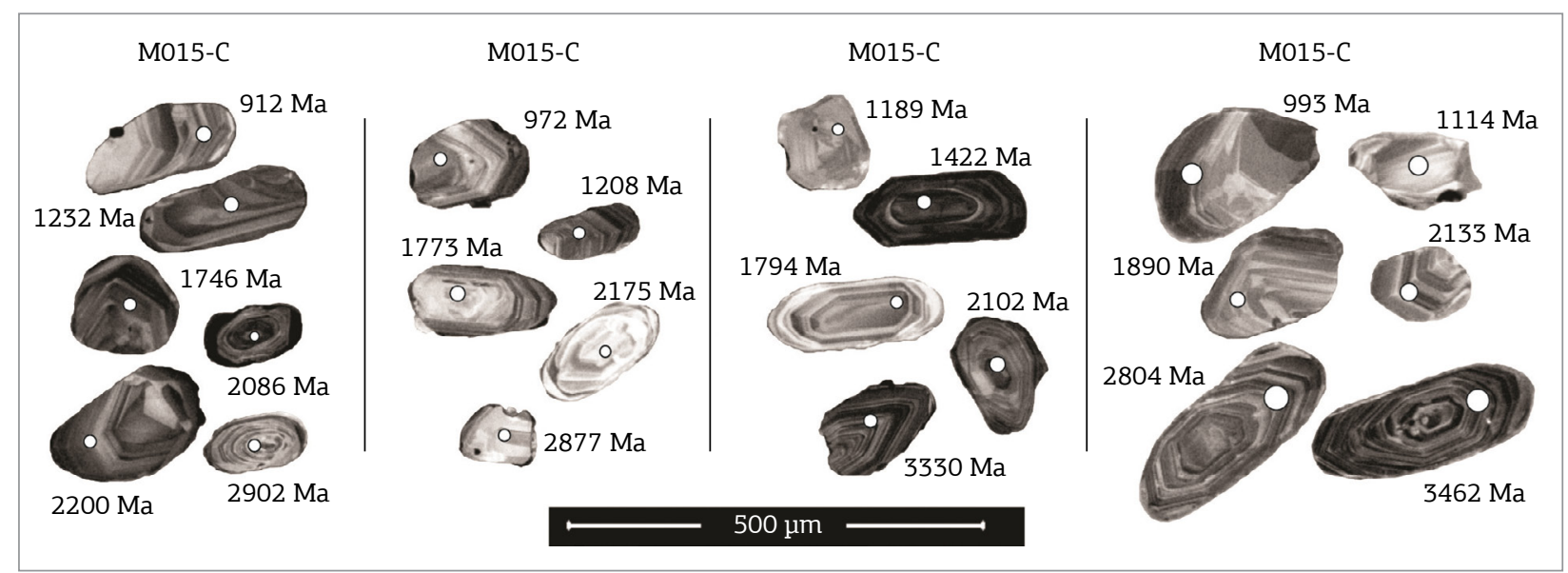

Figure 5. Cathodoluminescence images of zircons from samples M015-C, M021-B, M042-C and M031-A. 
2,560 and 2,690 Ma (Fig. 6B). The oldest concordant zircon yielded an age of $2,877 \pm 19 \mathrm{Ma}$, and the younger concordant zircon an age of $965 \pm 8 \mathrm{Ma}$.

\section{Santo Onofre Group - Sample M042-C}

Sample M042-C was collected in an outcrop at highway BA-351, near the highway BA-161 junction (677282 E, 8766314 N, Datum WGS89). The rock consists of a pure quartzite from Estreito Ridge. One hundred and thirty-eight (138) zircon grains were obtained from this sample, 117 of which were concordant within $10 \%$. The grains and fragments showed sizes between 260 and $100 \mu \mathrm{m}$. The observed morphology varies from prismatic to spherical, subangulous to rounded, zoned or untextured, rare inclusions, and a few fractures. The sample presents the main age peak at 1,790 Ma. Other peaks are 1,200, 1,350, 1,530, 1,960, 2,140, 2,420, 2,840, and 3,060 Ma (Fig. 6C). The oldest concordant zircon shows an age of $3,330 \pm 16 \mathrm{Ma}$, and the younger one the age of $1,189 \pm 30 \mathrm{Ma}$.

\section{Santo Onofre Group - Sample M031-A}

Sample M031-A was collected on top of Boqueirão Ridge (597224 E, 8804985 N, Datum WGS89). From this sample, 126 zircons showed less than $10 \%$ discordance and grain size varied from 290 to $80 \mu \mathrm{m}$. The grains and fragments are prismatic to spherical, mostly rounded, zoned or untextured. The main peak showed age $995 \mathrm{Ma}$, with $49 \%$ of the analyzed zircons. Other peaks showed ages of 1,100, 1,880, 2,030, 2,600, 2,700 and 3,240 Ma (Fig. 6D). One single concordant zircon yielded an age of $833 \pm 14 \mathrm{Ma}$. The oldest concordant zircon yielded an age of 3,462 $\pm 60 \mathrm{Ma}$. Thirty-eight (38) zircons from the youngest population yield a Concordia age of $989.3 \pm 2.9 \mathrm{Ma}(2 \sigma, \mathrm{MSWD}=0.089)$ (Fig. 7), and the youngest zircon shows an age of $971 \pm 16 \mathrm{Ma}$.

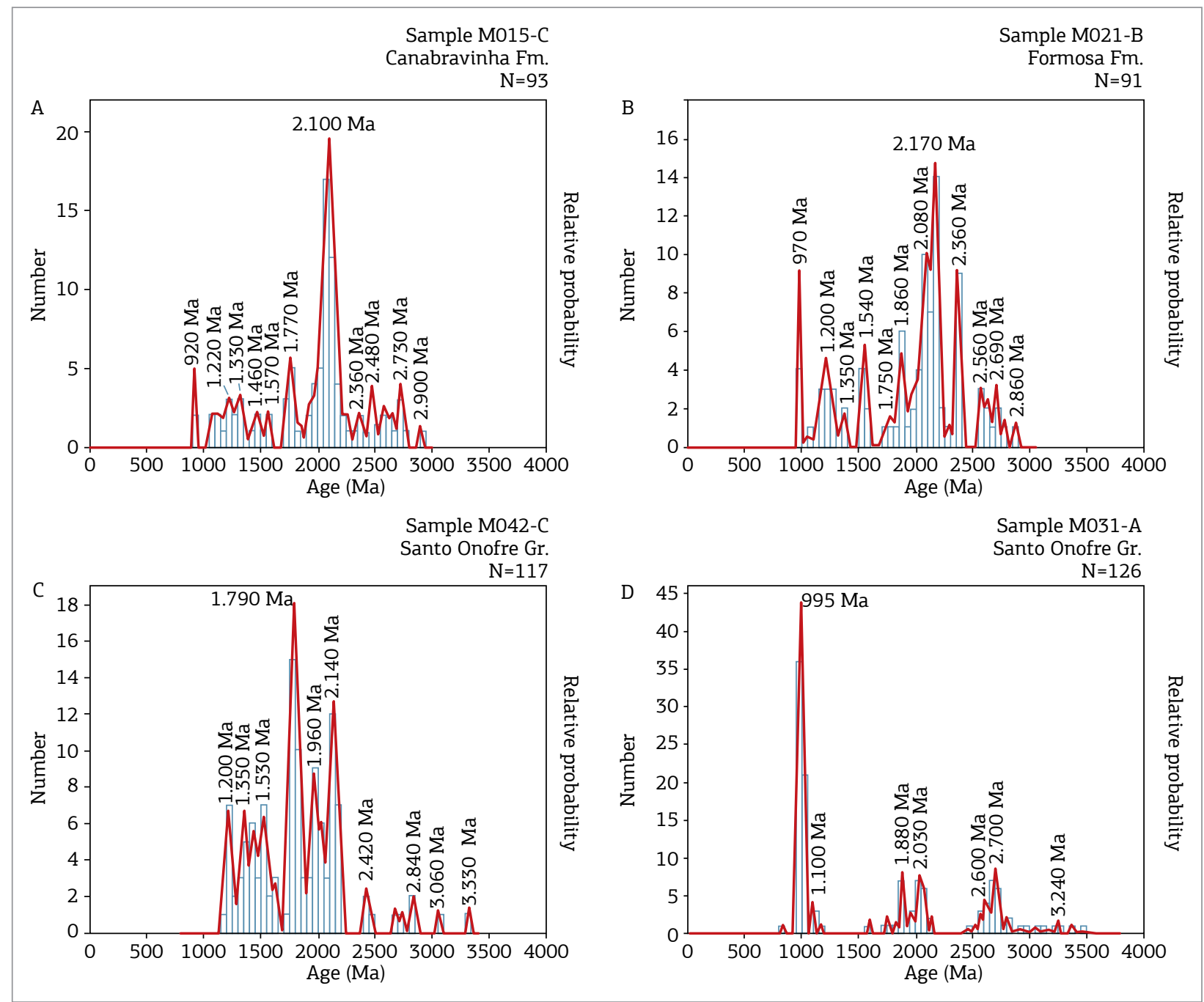

Figure 6. Combined histograms and probability density plots of detrital zircon ${ }^{207} \mathrm{~Pb} /{ }^{206} \mathrm{~Pb}$ ages of the samples from Rio Preto and Santo Onofre groups. 


\section{DISCUSSION}

\section{Possible source areas}

The Rio Preto and Santo Onofre basins occur along the junction of three important geological provinces: São Francisco, Borborema and Tocantins. Particularly, Santo Onofre Basin is

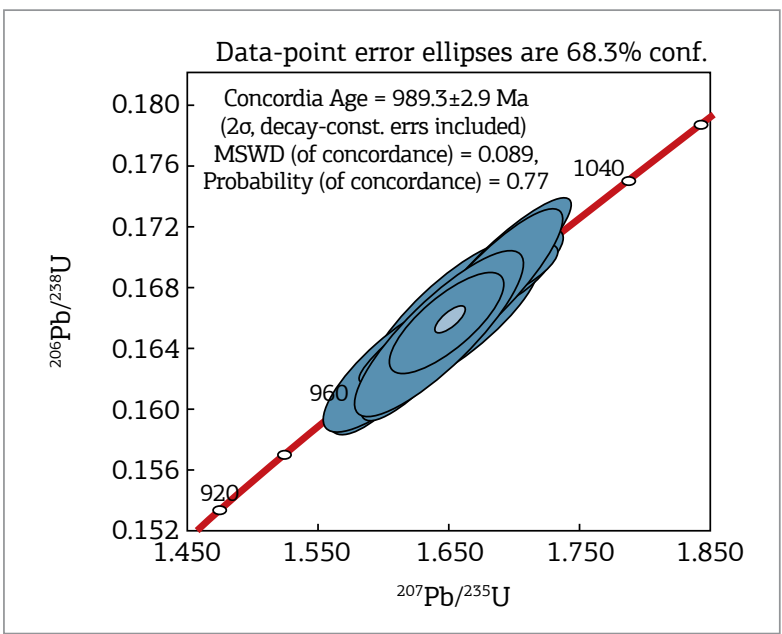

Figure 7. Concordia diagram for the youngest zircon population of Sample M031-A, Santo Onofre Group. entirely located in the interior of São Francisco Craton, and its major sources were probably from this crustal block. Rio Preto Basin developed on the NW limit of São Francisco Craton, on an ensialic rift or close to a magmatic arc (Caxito 2010; Caxito et al. 2014a). This basin shows a southern proximal part, with metadiamictites and coarse quarzites, and a northern distal domain with fine-grained quartzites and schists (Caxito 2010; Caxito et al. 2012; Uhlein et al. 2012), suggesting the cratonic block as the major source.

The Archean units of the craton are gneissic-migmatitic complexes of Tonalite-Trondhjemite-Granodiorite series (TTG) affinity and greenstone belts. Together, they form the most probable source for the Neo to Paleoarchean zircons found in our samples. The 3.3-3.4 Ga old zircon grains found in samples of Santo Onofre Group reproduce the Paleoarchean ages reported by Dantas et al. (2010) for gabbro-dioritic xenoliths of Gavião Block in northern São Francisco Craton, indicating that some of the oldest rocks of South America might be preserved in this cratonic fragment. The Paleoproterozoic of the Brazilian shield is marked by intense granitogenesis related to the Rhyacian-Orosirian Transamazonian orogeny (Fig. 8). Cristalândia do Piauí Complex (U-Pb ages of 2.13-2.11 Ga,

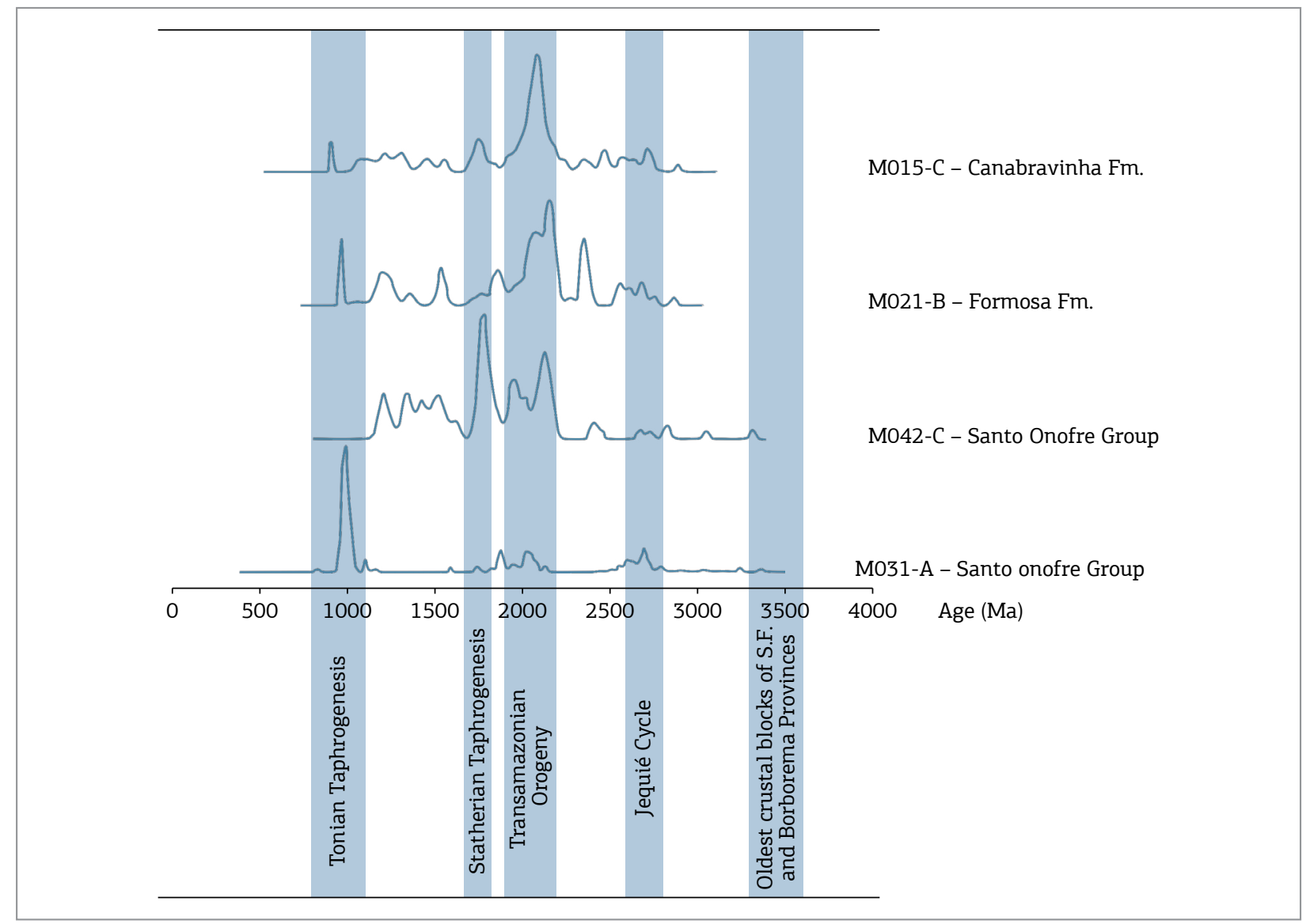

Figure 8. Probability density plots for the studied samples and main tectonic events recorded in São Francisco Craton. 
Aquino and Batista 2011) and Mansidão Granite (2046 Ma, Mascarenhas \& Garcia 1989) seem to have acted as the main sources for the Paleoproterozoic zircons.

Extensional events associated with bimodal magmatism and sedimentation within all three mentioned provinces mark the Upper Paleoproterozoic and Mesoproterozoic (Fig. 8). In São Francisco Craton, the onset of Espinhaço Supergroup deposition relates to an extensive acidic to intermediate volcanism recorded by Rio dos Remédios Group (Chapada Diamantina, 1.75 Ga, Brito Neves et al. 1979) and São Simão Synthem (Espinhaço Setentrional, 1.73 Ga, Dandefer et al. 2009) in Bahia State, as well as the metaigneous rocks of Conceição do Mato Dentro (1.72-1.70 Ga, Machado et al. 1989) in Minas Gerais State. Lagoa Real (ca. 1.7 Ga, Turpin et al. 1988, Cordani et al. 1992, Lobato et al. 2015) and Borrachudos (1.7 Ga, Dossin et al. 1993) granitoids represents the associated plutonism. The Statherian magmatic rocks located in the Bahia State mentioned above are the most probable sources for the Late Paleoproterozoic zircons.

The youngest zircon population of our samples was dated between 1.1 and $0.9 \mathrm{Ga}$, a period in which extensional events affected the São Francisco, Tocantins and Borborema provinces (Fig. 8). In São Francisco Craton and adjacent orogenic belts, Tonian events are represented by the mafic dyke swarms of Ilhéus-Olivença-Camacã (1.0 Ga, Correa-Gomes \& Oliveira 2000, Renne et al. 1990), Salvador (924 Ma, U-Pb in badelleyte, Heaman 1991), Espinhaço Range (0.85 Ga, Dandefer et al. 2009; Pedro Lessa Suite, 906 Ma, Machado et al. 1989) and São Francisco Basin (tolleitic dykes with Sm-Nd age of $984 \pm 110 \mathrm{Ma}$, Chaves 2001, Chaves \& Correia-Neves 2005). A-type granitic intrusions also occur in these regions, as exemplified by Salto da Divisa Suite (914-875 Ma, Silva et al. 2008), in Minas Gerais State, and Serra da Pintada Suite ( $969 \mathrm{Ma})$, in southern Piauí State. This last magmatism is possibly the main source for Tonian zircons. In Borborema Province, the main source of Neoproterozoic zircons is Cariris Velhos Belt (Brito Neves et al. 1995). A felsic magmatism dated between 1.1 and 0.92 Ga marks this belt (Brito Neves 1995; Van Schmus et al. 1995, 1999; Kozuch 2003; Santos et al. 2010; Guimarães et al. 2012; Caxito et al. 2014b). In Tocantins Province, the Goiás Magmatic Arc contains ca. 929 Ma metarhyolites located at the base of Arenopolis Sequence (Pimentel et al. 2000), and amphibolites from Araxá Group presented an age of $959 \mathrm{Ma}$ (Valeriano et al. 2004).

Sample M042-C, collected in the eastern border of Santo Onofre Rift, shows the largest Statherian (ca. $1767 \mathrm{Ma}$ ) age peak. The Statherian volcanics of the basal Espinhaço Supergroup in the areas to the south represent a possible source for these zircons. Sample M031-A, collected in the western border of the rift, shows the largest Tonian population (49\% of zircons). The younger peak $(n=38)$ of this sample yielded a Concordia age of $989.3 \pm 2.9 \mathrm{Ma}$, reproducing the age of Serra da Pintada granite suite, dated at $969 \pm 11 \mathrm{Ma}$ (Aquino \& Batista 2011), and located a few dozen kilometers from the basin (Fig. 1). The single 833 Ma concordant zircon found in the sample, although statistically not representative, is compatible with ages obtained in dykes occurring in the northern Espihanço Range (Danderfer et al. 2009). Samples of Canabravinha and Formosa Formations showed a very similar provenance record: a youngest peak of Tonian age, minor Mesoproterozoic peaks, a major age concentration between 1.9 and $2.1 \mathrm{Ga}$, and minor contribution of Neo-Mesoarchean sources.

\section{Stratigraphic correlations and implications for evolution of Rio Preto and Santo Onofre Groups}

The geochronological data presented here allow us to propose stratigraphic correlations between the investigated metasedimentary units and other Neoproterozoic sucessions exposed in Sáo Francisco craton and its margins. Santo Onofre Group, with a maximum depostional age ca. $975 \mathrm{Ma}$ and therefore coeval to Rio Preto Group, can be viewed as correlative of the pre-glacial lower Macaúbas Group (Duas Barras and Peixe Bravo formations) exposed in Araçuaí Belt (Pedrosa-Soares et al. 2001). Our data also supports Schobbenhaus (1996) suggestion that Santo Onofre and Rio Preto Groups were deposited in a NS-trending rift system, the Macaúbas - Santo Onofre - Rio Preto System, as also emphasized by Danderfer et al. (2009) and Caxito et al. (2014a).

The Tonian 912 Ma maximum depositional age obtained for Canabravinha Formation is in agreement with the $898 \mathrm{Ma}$ age peak determined by Caxito et al. (2014a). However, sample M021-B, from Formosa Formation, has yielded a Tonian maximum depositional age that diverges from the previous Paleoproterozoic age obtained by Caxito et al. (2014a). Further work is necessary to understand the dissimilar zircon spectra of Formosa Formation. Several limitations of the detrital zircon U-Pb methodology can influence the zircon spectra of a sample, such as zircon fertility of the sources, statistical representativety of the samples, paleogeography or differential sedimentary flux to the basin (Moecher \& Samson 2006; Andersen 2005, Cawood 2012). Regarding the paleogeography, Cawood (2012) also suggests that basins with syn-tectonic activity (e.g. rift basins) can show abrupt changes in sediment provenance and, therefore, detrital zircon spectra, since the hinterland setting during erosion vary spatialy and temporaly. Another possible explanation for this age disparity is that the Rio Preto sequence that crops out between the Boqueirão and Estreito ridges would be derived from units not captured by Rio Preto Group in the type locality.

The absence of Cryogenian-Ediacaran zircons or volcanic rocks in the studied units do not favor their correlation with 
the younger glaciogenic Macaúbas Group or with Bebedouro Formation (Chapada Diamantina). Santo Onofre Group, mostly composed of sand-rich rocks, would represent a less active shallow plataformal marine environment. Rio Preto Group, with metadiamictites, quartzites, pelitic and rhythmitic rocks, would represent a shallow to deep marine environment related with sedimentary gravity flows. The structural and stratigraphic data also allow for an interpretation of a triple junction at the NW border of the craton (Fig. 9). The NS-trending Santo Onofre Basin would represent an aborted, less active branch, while the E-W branch would evolve to a deeper and tectonically more active rift basin.

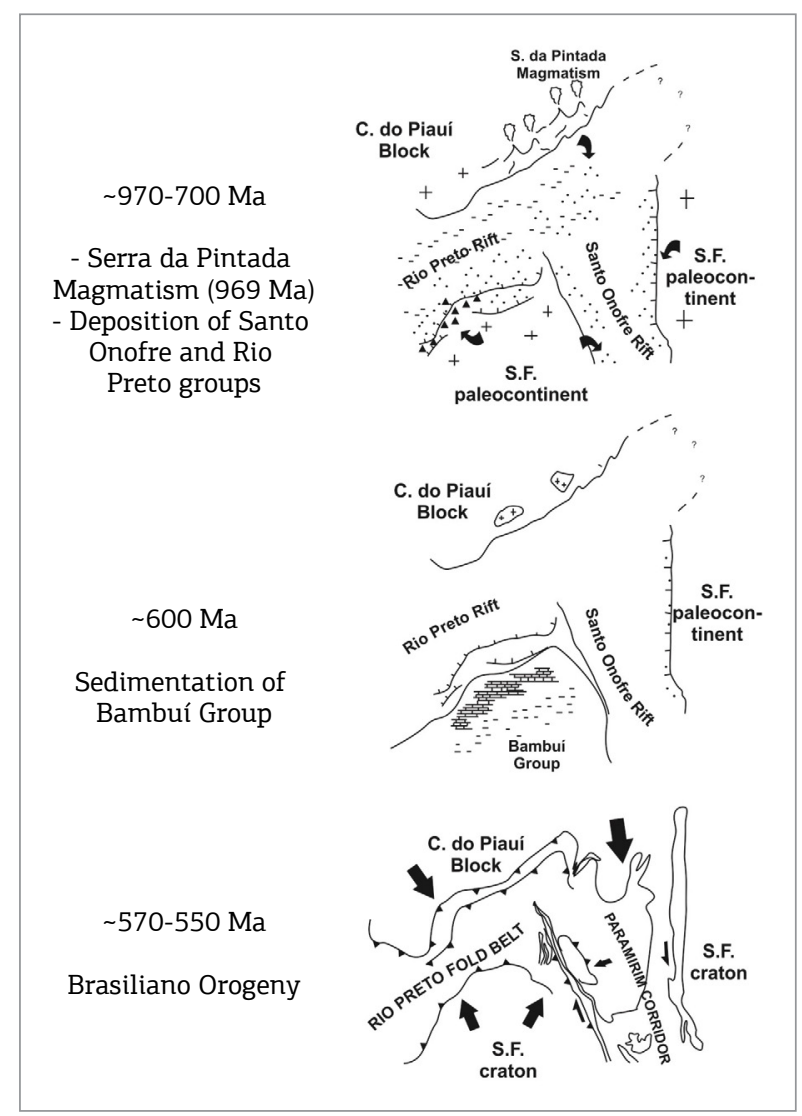

Figure 9. Evolutionary model of the study area.

\section{CONCLUSIONS}

Rio Preto and Santo Onofre Groups exposed in the northewestern São Francisco region represent two distinct but coeval rift-related metassedimentary sequences. Santo nofre Group, composed mainly of tabular sand-rich metasedimentary rocks, probably accumulated in a shallower plataformal environment. Rio Preto Group, subdivided into Formosa and Canabravinha Formations and made up of quartzites, phylites, laminated metarhitmites, metadiamictites and schists, is interpreted as a shallow to deep marine succession.

The obtained detrital zircon age spectra suggest Tonian (971 Ma) to Paleoarchean (3,462 Ma) sources for Santo Onofre Group. Rio Preto Group was sourced by Tonian (912 Ma) to Neo-Mesoarchean (2,868 Ma) units. The main age peaks for both groups point towards the Rhyacian basement (Cristalândia do Piauí Complex and Mansidáo Granite) and Espinhaço Supergroup basal volcanic as their main sources.

Santo Onofre Group can be viewed as correlative of the pre-glacial Macaúbas Group (Duas Barras and Peixe Bravo Formations), and of Espinhaço Supergroup, as previously suggested. Our data also indicates that Santo Onofre and Rio Preto Groups were deposited in rift triple junction developed on the northwestern border of São Francisco Craton. The N-S-trending Santo Onofre branch would correspond to a less active, shallow branch, while the E-W-oriented Rio Preto branch would correspond to a deeper and more evolved branch, possibly connected with the passive margin of Riacho do Pontal Belt.

\section{ACKNOWLEDGEMENTS}

We thank the financial support by the Coordenação de Aperfeiçoamento de Pessoal de Nivel Superior (CAPES), the Programa de Pós-Graduação em Geologia - Instituto de Geociencias of the Universidade Federal de Minas Gerais, and the Projeto Triângulo Mineiro (CODEMIG/UFMG). AU, FAC, ID and ACPS are Fellows of the Brazilian Research Council (CNPq) and acknowledge for the support received.

\section{REFERENCES}

Affatton P., Kalsbeek F., Boudzoumou F., Trompette R., Thrane K., Frei R. 2016. The Pan-African West Congo belt in the Republico of Congo (Congo Brazzaville): Stratigraphy of the Mayombe and West Congo Supergroups studied by detrital zircon geochronology. Precambrian Research, 272:185-202.

Alkmim F.F., Marshak S., Fonseca M.A. 2001. Assembing West Gondwana in the Neoproterozoic: Clues from the São Francisco craton region, Brazil. Geology, 29:319-322.

Almeida F.F.M., Brito Neves B.B., Carneiro C.D.R. 2000. Origin and evolution of the South American platform. Earth-Science Reviews, 50:77-111.
Andersen T. 2005. Detrital zircon as tracers of sedimentary provenance: limiting conditions from statistics and numerical simulation. Chemical Geology, 216:249-270.

Andrade Filho E.L., Neves J.P., Guimarães J.T. (orgs). 1994. Programa levantamentos geológicos básicos do Brasil. Folhas Santa Rita de Cássia (SC.23-Z-C) e Formosa do Rio Preto (SC.23-Y-D), escala 1:250.000. SME/CPRM, Brasília: 68 p.

Aquino M.R. \& Batista I.H., 2011. Geologia e recursos minerais da folha Avelino Lopes - SC.23-Z-A-III, escala 1:100.000. Programa Geologia do Brasil, CPRM. Brazilian Geological Survey, Teresina, PI, 88 pp. 
Arcanjo J.B.A., Braz Filho P.A. (Orgs.). 2001. Curimatá, folha SC.23-Z-A, Corrente, folha SC.23-Y-B (parcial), Xique-Xique, folha SC.23-Z-B (parcial): estados da Bahia e do Piauí. Brasília: CPRM. 84 p.il. 1 mapa anexo. Escala 1:250.000. Programa Levantamentos Geológicos Básicos do Brasil - PLGB.

Barbosa J.S.F. 1982 O manganês do oeste da Bahia. Dissertação de mestrado, Universidade Federal da Bahia, p. 129.

Barbosa J.S.F., Domingues J.M.L. 1996. Texto Explicativo para o mapa Geológico do Estado da Bahia ao Milionésimo. SICM/SGM, Salvador, Bahia, Brasil, 440 pp.

Brito Neves B.B., Kawasshita K., Cordani U.G., Delhal J. 1979. A evolução geocronológica da Cordilheira do Espinhaço: dados novos e integração. Revista Brasileira de Geociências, 9(1):71-85.

Brito Neves B.B. 1995. Crátons e Faixas Móveis. Boletim IG-USP, Séries Didáticas, 7:187.

Brito Neves B.B., Van Schmus W.R., Santos E.J., Campos Neto M.C.C., Kozuch M. 1995. O evento Cariris Velhos na Província Borborema: integração de dados, implicações e perspectivas. Revista Brasileira de Geociências, 25(4):279-296.

Chaves A.O. 2001. Enxames de diques máficos do setor sul do Cráton do São Francisco-MG. Tese de Livre Docência, Instituto de Geociências. Universidade de São Paulo, p. 153.

Cawood P.A., Hawkesworth C.J., Dhuime B. 2012. Detrital zircon record and tectonic setting. Geology, 40(10):875-878.

Caxito F.A. 2010. Evolução tectônica da Faixa Rio Preto, Noroeste da Bahia/Sul do Piauí. Dissertação de Mestrado, Instituto de Geociências, Universidade Federal de Minas Gerais, p. 151.

Caxito F.A., Uhlein A., Sanglard J.C.D, Gonçalves Dias T., Mendes M.C.O. 2012. Depositional systems and stratigraphic review proposal of the Rio Preto Fold Belt, northwestern Bahia/southern Piauí. Revista Brasileira de Geociências, 42(3):523-538.

Caxito F.A., Dantas E.L., Stevenson R., Uhlein A. 2014a. Detrital zircon $(\mathrm{U}-\mathrm{Pb})$ and $\mathrm{Sm}-\mathrm{Nd}$ isotope studies of the provenance and tectonic setting of basins related to collisional orogens: the case of the Rio Preto fold belt on the northwest São Francisco Craton margin, NE Brazil. Gondwana Research, 26(2):741-754.

Caxito, F.A., Uhlein, A., Dantas, E.L., 2014b. The Afeição augen-gneiss Suite and the record of the Cariris Velhos Orogeny (1000-960 Ma) within the Riacho do Pontal fold belt, NE Brazil. Journal of South American Earth Sciences, 51:27-12.

Caxito F.A., Uhlein A., Morales L.F.G, Egydio-Silva M., Sanglard J.C.D., Dias T.G., Mendes M.C.O. 2014c. Structural analysis of the Rio Preto fold belt (northwestern Bahia / southern Piauí), a doubly-vergent asymmetric fan developed during the Brasiliano Orogeny. Anais da Academia Brasileira de Ciencias, 86:1101-1113.

Caxito F.A., Uhlein A., Dantas E.L., Stevenson R., Pedrosa-Soares A.C. 2015. Orosirian (ca. $1.96 \mathrm{Ga}$ ) mafic crust of the northwestern São Francisco Craton margin: Petrography, geochemistry and geochronology of amphibolites from the Rio Preto fold belt basement, NE Brazil. Journal of South American Earth Sciences, 59:95-111.

Caxito F.A., Uhlein A., Dantas E.L., Stevenson R., Salgado S.S., Dussin I.A., Sial A.N. 2016. A complete Wilson Cycle recorded within the Riacho do Pontal Orogen, NE Brazil: Implications for the Neoproterozoic evolution of the Borborema Province at the heart of West Gondwana. Precambrian Research, 282:97-120.

Caxito F.A., Uhlein A., Dantas E., Stevenson R., Egydio-Silva M., Salgado S.S. 2017. The Rio Preto and Riacho do Pontal belts. In. Heilbron M., Cordani U.G, Alkmin F.F. (eds.), São Francisco Craton, Eastern Brazil. Regional Geology Reviews. pp.221-239.
Chaves A.O. \& Correia-Neves J.M. 2005. Radiometric ages, aeromagnetic expression, and general geology of mafic dykes from southeastern Brazil and implications for African-South American correlations. Journal of South American Earth Sciences, 19(3):387-397.

Chemale F., Dussin I.A., Alkmim F.F., Martins M.S., Queiroga G., Armstrong R., Santos M.N., 2012. Unravelling a Proterozoic basin history through detrital zircon geochronology: the case of the Espinhaço Supergroup, Minas Gerais, Brazil. Gondwana Research, 22:200-206.

Cordani U.G., Iyer S.S., Taylor P.N., Kawashita K., Sato K., McReath I. 1992. Pb-Pb, Rb-Sr, and K-Ar sistematic of the Lagoa Real uranium province (south-central Bahia, Brazil) and the Espinhaço Cycle (ca. 1.5-1.0 Ga). Journal of South American Earth Sciences, 1:33-46.

Corrêa-Gomes L.C. \& Oliveira E.P. 2000. Radiating 1.0 Ga mafic dyke swarms of Eastern Brazil and Western Africa: evidence of post-assembly extension in the Rodinia Supercontinent?. Gondwana Research, 3(3):325-332.

Danderfer A. \& Dardenne M.A. 2002. Tectonoestratigrafia da bacia Espinhaço na porção centro-norte do cráton do São Francisco: registro de uma evolução poliistórica descontínua. Revista Brasileira de Geociências, 32(4):449-460.

Danderfer A., DeWaele B., Pedreira A.J., Nalini H.A. 2009. New geochronological constraints on the geological evolution of Espinhaço basin within the São Francisco Craton-Brazil. Precambrian Research, 170:116-128.

Dantas E.L., Brito Neves B.B., Fuck R.A., 2010. Looking for the oldest rocks of South America: Paleoarchean orthogneiss of the Sobradinho Block, northernmost foreland of the São Francisco Craton, Petrolina, Pernambuco, Brazil. In: VII SSAGI - South American Symposium on Isotope Geology, Brasília, CD-ROM, pp. 137-140.

Dossin I.A.; Dossin T.M.; Charvet J.; Cocherie A., Rossi P. 1993. Single-zircon dating by step-wise $\mathrm{Pb}$ - evaporation of Middle Proterozoic Magmatismo in the Espinhaço Range, Southeastern São Francisco Craton (Minas Gerais, Brazil). In: SIMPÓSIO DO CRÁTON DO SÃO FRANCISCO, 2. Salvador, 1993. Anais...p.39-42.

Egydio-Silva M. 1987. O sistema de dobramentos Rio Preto e suas relações com o Cráton São Francisco. Tese de doutorado, Instituto de Geociências, Universidade de São Paulo, São Paulo, 95p.

Egydio-Silva M., Karmann I., Trompette R.R. 1989. Litoestratigrafia do Supergrupo Espinhaço e Grupo Bambuí no noroeste do estado da Bahia. Revista Brasileira de Geociências, 19(2):101-112.

Gonçalves L., Alkmim F.F., Pedrosa-Soares A.C., Dussin I.A., Valeriano C.M., Lana C., Tedeschi M. 2016. Granites of the intracontinental termination of a magmatic arc: an example from the Ediacaran Araçuaí orogen, southeastern Brazil. Gondwana Research, 36:439-458.

Guimarães I.P., Van Schmus W.R., Brito Neves B.B., Bittar S.M.B., Silva Filho A.F., Armstrong R. 2012. U-Pb zircon ages of orthogneisses and supracrustal rocks of the Cariris Velhos belt: onset of Neoproterozoic rifting in the Borborema Province, NE Brazil. Precambrian Research, 192-195:52-77.

Heaman L. 1991. U-Pb dating of giant radiating dyke swarms: potential for global correlation of mafic events. In: International Symposium on mafic dykes, São Paulo, Brazil, Extended Abstract, p. 7-9.

Inda H.A.V., Barbosa J.F. 1978. Texto explicativo para o mapa geológico do Estado da Bahia, escala 1:1.000.000. Salvador, SME/CPM, 137 pp.

Jackson S.E., Pearson N.J., Griffin W.L., Belousova E.A. 2004. The application of laser ablation-inductively coupled plasma-mass spectrometry to in situ U-Pb zircon geochronology. Chemical Geology, 211:47-69. 
Kozuch M. 2003. Isotopic and trace element geochemistry of Early Neoproterozoic gneissic and metavolcanic rocks in the Cariris Velhos Orogen of the Borborema Province, Brazil, and their bearing on tectonic setting. Unpublished PhD Thesis, University of Kansas, 199 pp.

Klotzli U., Klotzli E., Gunes Z., Kosler J. 2009. Accuracy of laser ablation $\mathrm{U}-\mathrm{Pb}$ zircon dating: Results from a test using five different reference zircons. Geostandards and Geoanalytical Research, 33(1):5-15.

Kuchenbecker M., Pedrosa-Soares A.C., Babinski M., Fanning M. 2015. Detrital zircon age patterns and provenance assessment for pre-glacial to post-glacial successions of the Neoproterozoic Macaúbas Group, Araçuaí orogen, Brazil. Precambrian Research, 266:12-26.

Lobato L.M., Pimentel M.M., Cruz S.C.P, Machado N., Noce C.M., Alkmim F.F. 2015. U-Pb geochronology of the Lagoa Real uranium district, Brazil: Implications for the age of the uranium mineralization. Jornal of South American Earth Sciences, 58:129-140.

Ludwig K.R., 2008. User's manual for Isoplot 3.6. A geochronological toolkit for Microsoft Excel. Special Publication, No. 4. Berkeley Geochronologic Center, Berkeley, USA.

Machado N., Schrank A., Abreu F.R., Knauer L.G., Almeida-Abreu P.A., 1989. Resultados preliminares da geocronologia U-Pb na Serra do Espinhaço Meridional. Boletim do Núcleo Minas Gerais, 10:171-174.

Mascarenhas J.F. \& Garcia T.M. 1989. Mapa geocronológico do Estado da Bahia. Escala 1:1.000.000. Texto explicativo. Salvador, SME/SGM, 186, p. 1, mapa.

Moecher D.P. \& Samson S.D. 2006. Differential zircon fertility of source terranes and natural bias in the detrital zircon record: Implications for sedimentary provenance analysis. Earth and Planetary Science Letters, 247:252-266.

Pedrosa-Soares A.C. \& Alkmin F.F. 2011. How many rifting events preceded the development of the Araçuai-West Congo orogen? Geonomos, 19(2):244-251.

Pedrosa-Soares A.C., Noce C.M., Wiedemann C.M., Pinto C.P. 2001. The Araçuaí-West Congo orogen in Brazil: An overview of a confined orogen formed during Gondwanland assembly. Precambrian Research, 110:307-323.

Pedrosa-Soares A.C., Alkmim F.F., Tack L., Noce C.M., Babinski M., Silva L.C., Martins-Neto M. 2008. Similarities and differences between the Brazilian and African counterparts of the Neoproterozoic Araçuaí-West Congo Orogen. In: Pankhurst J.R., Trouw R.A.J., Brito Neves B.B., De Wit M.J.(eds) West Gondwana: Pre-Cenozoic Correlations across the South Atlantic Region. Geological Society of London, Special Publication, 294:153-172.

Pimentel M.M., Fuck R.A., Jost H., Ferreira Filho C.F., Araújo S.M. 2000. The basement of the Brasília Fold belt and the Goiás Magmatic Arc. In: Cordani U.G., Milani E.J., Thomaz Filho A., Campos D.A. (eds.) Tectonic Evolution of South America. Rio de Janeiro, 31ST IGC, 195-229.

Renne P.R., Onstott T.C., D’Agrella-Filho M.S., Pacca I.G., Teixeira W. 1990. 40Ar/39Ar dating of 1.0- $1.1 \mathrm{Ga}$ magnetizations from the São Francisco and Kalahari cratons: tectonic implications for PanAfrican and Brasiliano mobile belts. Earth and Planetary Science Letters, 101:349-366.

Santos E.J., Van Schmus W.R., Kozuch M., Brito Neves B.B. 2010. The Cariris Velhos tectonic event in Northeast Brazil. Journal of SouthAmerican Earth Sciences, 29: 61-76.

Schobbenhaus C. 1996. As tafrogêneses superpostas Espinhaço e Santo Onofre, Estado da Bahia: revisão e novas propostas. Revista Brasileira de Geociências, 26 (4): 265-276.
Silva L.C. Pedrosa-Soares A.C. Teixeira L. Armstrong R. 2008. Tonian rift-related, A-type continental plutonism in the Araçuaí Orogen, eastern Brazil: new evidence for the breakup stage of the São Francisco Congo Paleocontinent. Gondwana Research, 13:527-537.

Slama J., Kosler J., Condon D.J., Crowley J.L., Gerdes A., Hanchar J.M., Horstwood M.S.A., Morris G.A., Nasdala L., Norberg N., Schaltegger U.,Schoene B., Tubrett M.N., Whitehouse M.J., 2008. Plesovice zircon - a newnatural reference material for $\mathrm{U}-\mathrm{Pb}$ and $\mathrm{Hf}$ isotopic microanalysis. Chemical Geology, 249:1-35.

Straathof G.B. 2011. Neoproterozoic Low Latitude Glaciations: An African Perspective. Ph.D. Thesis, University of Edinburgh, 285 pp.

Thiéblemont D., Castaing C., Billa M., Bouton A., Préat A. 2009. Notice explicative de la carte géologique et des ressources minérales de la République Gabonaise à 1/1000000. Programme Sysmin 8 ACP GA 017, Ministère des Mines, du Pétrole, des Hydrocarbures. Direction Générale des Mines et de la Géologie. p. 384.

Turpin L., Maruèjol P., Cuney M. 1988.U-Pb, Rb-Sr and Sm-Nd chronology of granitic basement, hydrotermal albitites and uranium mineralization, Lagoa Real, South Bahia, Brazil. Contributions to Mineralogy and Petrology, 98:139-147.

Uhlein A. \& Pedreira A.J. 1989. Considerações sobre a geologia estrutural, tectônica e fácies sedimentares do Espinhaço Setentrional e Chapada Diamantina (BA). In: SBG, Simpósio de Geologia de Minas Gerais, $5^{\circ}$ Simpósio de Geologia de Brasília, 1, Belo Horizonte, Anais..., p. 180-183.

Uhlein A., Caxito F.A., Sanglard J.C.D., Uhlein G.J., Suckau G.L. 2011. Estratigrafia e tectônica das faixas neoproterozóicas da porção norte do Craton do São Francisco. Geonomos, 19(2):8-31.

Uhlein A., Caxito F.A., Egydio-Silva M., Barbosa J.S.F. 2012. Faixa de dobramentos Rio Preto e Riacho do Pontal. In: Barbosa J.S.F. (Coord.) Geologia da Bahia Pesquisa e Atualização (v. 2, 87-130). Salvador: Convênio CBPM-UFBA.

Valeriano C.M., Machado N., Simonetti A., Valladares C.S., Seer H., Simões L.S. 2004. U-Pb geochronology of the southern Brasília belt (SE-Brazil): sedimentary provenance, Neoproterozoic orogeny and assembly of West Gondwana. Precambrian Research, 130:27-55.

Van Achterbergh E., Ryan C.G., Jackson S.E., Griffin W.L. 2001. Data reduction software for LA-ICP- MS: appendix. In: Sylvester P.J. (Ed.), Laser Ablation-ICP Mass Spectrometry in the Earth Sciences: Principles and Applications (vol. 29, 239-243). Ottawa: Mineralogy Association ofCanada (MAC) Short Course Series.

Van Schmus W.R., Brito Neves B.B., Hackspacher P., Babinski M. 1995. U-Pb and Sm-Nd geochronological studies of the Eastern Borborema province, Northeast Brazil: initial conclusions. Journal of South American Earth Sciences, 8:267-288.

Van Schmus W.R., Fetter A.H., Brito Neves B.B., Williams I.S. 1999. Ages of detrital zircon populations from Neoproterozoic supracrustal units in NE Brazil: Implications for assembly of West Gondwanaland. Geological Society of America, Abstract Programs, 31(7):A-299

Vasconcelos A.M., Kosin M., Souza J.D., Valente C.R., Neves J.P., Heineck C.A., Lacerda Filho J.V., Teixeira L.R., Borges V.P., Bento R.V., Guimarães J.T., Neves J.P., Oliveira I.W.B., Gomes, I.P., Malouf R.F., Carvalho L.M., Abreu Filho W., 2004. Folha SC.23 - Rio São Francisco. In: Schobbenhaus C., Gonçalves J.H., Santos J.O.S., Abram M.B., Leão Neto R., Matos G.M.M., Vidotti R.M., Ramos M.A.B., Jesus J.D.A. (eds.), Carta Geológica do Brasil ao Milionésimo, Sistema de Informações Geográficas. Programa Geologia do Brasil, CPRM, Brasília. CD-ROM.

Available at www.sbgeo.org.br 